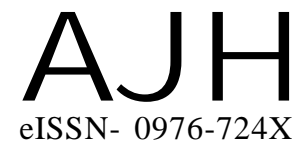

Received : 11.01.2017

Accepted : 30.05.2017

Members of the Research Forum

Associated Authors:

${ }^{1}$ Krishi Vigyan Kendra,

BIRCHANDRAMANU (TRIPURA)

INDIA
Author for correspondence :

A.K. SINGH

ICAR-Central Research Institute for Jute and Allied Fibres, Barrackpore, KOLKATA (W.B.) INDIA

Email : singhak30@gmail.com
THEASIAN JOURNAL OF HORTICULTURE

Volume 12 | Issue 1 | June, 2017 | 165-168

Visit us -www.researchjournal.co.in

A CASE STUDY

DOI : 10.15740/HAS/TAJH/12.1/165-168

\section{Integrated crop management to enhance vegetable productivity and farm income through INM and IPM practices}

\section{A.K. SINGH AND INGITA GOHAIN ${ }^{1}$}

ABSTRACT : Vegetable production is an important component of agriculture and also an essential part of a balanced human diet. In recent years, vegetable production has also become an income generating enterprise for those farmers who are located close to markets and road sides. Local varieties and practices are of low productivity, prone to pests and grown without proper fertilizer management resulting in poor yield and poor soil fertility. Modern technologies are often inappropriate for them due to lack of knowledge and training. However, a combination of traditional and appropriate modern technology like INM, IPM and improved variety can reap the good harvest of vegetables and support livelihood and nutritional security of farmers. Considering the importance of vegetable production and to meet the market demand of tomato, chilli and brinjal crop, on-farm research trials (INM and IPM system) were conducted under IIHR-NE component programme during 2013-15 in South Tripura district of India.

KEY WORDS : INM, IPM practices, Enhance vegetable productivity, Farm income

HOW TO CITE THIS ARTICLE : Singh, A.K. and Gohain, Ingita (2017). Integrated crop management to enhance vegetable productivity and farm income through INM and IPM practices. Asian J. Hort., 12(1) : 165-168, DOI : 10.15740/HAS/TAJH/12.1/165-168. 